\title{
Narrativas sobre a América: o trauma e suas expressões temporais
}

\author{
Narratives about America: the trauma and its temporal expressions
}

\author{
Fabiana de Souza Fredrigo ${ }^{1}$ \\ Libertad Borges Bittencourt ${ }^{2}$
}

\begin{abstract}
Resumo
Ao partir do pressuposto de que a escritura ensaística funda um lugar para a América no Ocidente, pretendemos indicar de que maneira tais narrativas configuraram um campo para a interpretação do continente. A hipótese é que se essa interpretação peculiar definiu um "lugar no mundo" para a cultura latino-americana, assim o fez na medida em que constituiu sentido à experiência histórica por meio da noção de trauma. Para discorrer sobre essa hipótese, priorizamos o ensaio em um tempo longo, trazendo para análise tanto as narrativas de Octávio Paz, Carlos Fuentes e Tomás Moulian quanto as de Francisco Bilbao e Justo Sierra. Ainda, como contraponto, recorremos aos discursos de Simón Bolívar e Gabriel García Márquez, pois esses expressam igualmente o trauma latino-americano. Essa trajetória é relevante porque, em nossa análise, identificamos como traço comum a essas escrituras o trauma. A escolha dessas narrativas, em períodos distintos, porém conexos, também é perpassada pelo propósito de demonstrar o quanto a "história escrita" da América Latina ainda hoje é devedora da ensaística.
\end{abstract}

Palavras-chave: América Latina; trauma; ensaio.

\begin{abstract}
With the assumption that the essay writing establishes a place for America in the West, we intend to indicate how such narratives configured a field to the interpretation of the continent. The hypothesis is that this peculiar interpretation defined a "place in the world" to the Latin American culture, it did so when it made sense to the historical experience of the concept of trauma. To discuss about this hypothesis, we prioritize the essay through a long period of time, bringing to the analysis the narratives of Octavio Paz, Carlos Fuentes and Thomas Moulian as well as Francisco Bilbao and the Justo Sierra. Still, as a counterpoint, we turn to the speeches of Simon Bolivar and Gabriel García Márquez, as these equally express the Latin American trauma. This trajectory is relevant because, in our analysis, we identified the common thread to these scriptures -
\end{abstract}

\footnotetext{
${ }^{1}$ Professora Associada I da Universidade Federal de Goiás, doutora pela Universidade Estadual Paulista, com pós-doutorado pela Universidade de São Paulo. Projeto em andamento: História, ensaio e literatura: a escritura do trauma na América Latina contemporânea. Endereço para correspondência: Rua T 65, n. 1077, Edifício Borges Landeiro, Bloco B. Setor Bueno - Goiânia - Goiás, CEP 74230-120. E-mail: fabianafredrigo@gmail.com.

${ }^{2}$ Professora Associada III da Universidade Federal de Goiás, doutora pela UnB, com pós-doutorado na UFMG. Título das pesquisas em andamento: $\mathrm{O}$ crisol americano e as identidades nacionais: o lugar das Américas no pensamento hispano-americano nos séculos XIX e XX; Viver para contar - o diário e as missivas do general granadino Francisco de Paula Santander no exílio (1829-1832). Endereço para correspondência: Av. T4, n. 877, apto. 901 - Setor Bueno - Goiânia - Goiás, CEP 74230-035. Email: libertadborges@gmail.com
}

\section{CANPHLAC}

Revista Eletrônica da ANPHLAC, ISSN 1679-1061, Nº. 17, p. 59-86, jul./dez. 2014. http://revista.anphlac.org.br/ 
the trauma. The choice of these essayists, at different times, but related, is also pervaded the purpose of demonstrating how the "writing history" of Latin America today is indebted to the essay.

Keywords: Latin America; trauma; essay.

Artigo recebido em: 21/07/2014

Artigo aprovado para publicação em: 04/10/2014

América Latina é uma cultura. Não é fácil defini-la e nem sequer descrevêla. Os que melhor têm expressado essa realidade esquiva são os escritores. Mas nenhum desses poemas e romances é ou pode ser um retrato realista; todas essas obras são imagens ou, mais exatamente, imaginações do que somos. Enfim, posso dizer algo, ao menos: América Latina é uma realidade verbal. Ou seja: uma língua. E aquele que diz língua, diz: visão de mundo. Que é uma visão de mundo? Não é unicamente uma concepção ou uma ideia: é uma ação e uma criação, um ethos e um conjunto de obras. É o mundo feito de muitos mundos. Nossa realidade é plural e diversa, é um diálogo de povos que falam, na mesma língua, coisas que são distintas e comuns, a um só tempo.

Octávio Paz

A proposta deste artigo é discutir sobre o lugar ocupado pela América, considerando as narrativas que legitimaram a "evidência" de uma expressão americana. Diante disso, um alerta imediato: não se trata de buscar uma "essência latinoamericana"; ao invés disso, o que se pretende é indicar de que maneira as narrativas constituíram um campo para a interpretação de culturas que, a despeito de suas diferenças, passaram a se reconhecer e ser reconhecidas a partir da denominação “América Latina". Dentre as escritas que contribuíram para a interpretação nomeada, está o ensaio, que é utilizado, neste artigo, como fonte preferencial. Partimos das interpretações de Octávio Paz, Carlos Fuentes e Tomás Moulian, ao mesmo tempo em que retomamos os ensaístas dos oitocentos, Francisco Bilbao e Justo Sierra, para estabelecer uma permanência: o trauma com a colonização e o processo das independências. Visitar os ensaístas, em dois tempos, também tem outro propósito: demonstrar que a "história escrita" da América Latina ainda hoje é devedora da ensaística. Uma das hipóteses aqui sustentada, que assume a dívida da história para com o ensaio, não é nova. Na verdade, nova é a tentativa de demonstrar as permanências

\section{GANPHLAC}

Revista Eletrônica da ANPHLAC, ISSN 1679-1061, No. 17, p. 59-86, jul./dez. 2014. http://revista.anphlac.org.br/ 
instiladas em escritas que tentaram, ao longo dos tempos, estabelecer fronteiras disciplinares. A afirmação da centralidade do ensaio para a nossa hipótese deve vir acompanhada de uma advertência, cujo objetivo é o de ratificar a mesma centralidade: o desvendamento da cultura latino-americana e as polêmicas intelectuais encontraram no ensaio sua forma predileta de expressão, no século XIX. A permanência desse gênero reitera que o apego e o apelo ao ensaio não podem ser explicados apenas pela ausência de outro campo discursivo. Nesse sentido, asseveramos que o discurso científico acadêmico, afirmado posteriormente, não substitui a narrativa ensaística - esses discursos coexistem. Em razão da coexistência mencionada, o ensaio encontra-se no "entre", justamente no que empresta porosidade e movimento às fronteiras: ele é história, é literatura, é filosofia.

Para o século XIX, o que impulsionou a escrita e a disseminação de textos considerados fundadores foi a busca de argumentos capazes de levar a uma ruptura simbólica com a colonização. Essas escritas, que se encaixam na perspectiva ensaística, tratam, em grande medida, das percepções dos letrados sobre os acontecimentos do presente e do passado, mas servem, sobretudo, para projetar mudanças. Ao incorporar o combate com o passado que quer superar, a escrita constrói uma relação peculiar com o próprio tempo, apontando, obrigatoriamente, para mudanças de signo e de significado constantes. Assim, escrever era inventar uma América, secularizando a relação com o passado. Por sua vez, a secularização respondia à condenação de uma tradição para legitimar a invenção de uma genealogia cultural que permitisse à América vincular-se às "luzes do século" e à "civilização moderna" (LEMPÉRIÈRE, 2008). Nesse contexto, concepções como civilização, luzes e sociabilidade se tornaram parte do imaginário e do ideário liberais, ampliados devido a novos modelos de associações fundamentadas em princípios inéditos de convivência social. Dessa maneira, a presença de uma escrita peculiar - que, por ser combativa, exigia a literalidade do ensaio - não é novidade para a América Latina. Se, no século XX, autores como Paz e Fuentes continuaram a utilizarse dessa forma de expressão é porque essa escrita permite o estabelecimento de uma narrativa que singulariza a América. Nesse sentido, parece-nos relevante investigar as relações entre a história e a escrita ensaística para compreender de que forma a singularidade americana é constituída temporalmente.

\section{GANPHLAC}

Revista Eletrônica da ANPHLAC, ISSN 1679-1061, No. 17, p. 59-86, jul./dez. 2014. http://revista.anphlac.org.br/ 


\section{Narrativa, temporalidade e trauma}

A narrativa sobre a América Latina, construída e legitimada pelo ensaio, está entrelaçada a uma temporalidade e a um sentido singulares. Assim, a primeira tarefa é a de perscrutar de que maneira as narrativas sobre esse lugar entrelaçam as temporalidades $^{3}$ americana originária, europeia e das sociedades implantadas - essa última entendida como o fruto da colonização (MARTINS, 2004). A temporalidade europeia (hispânica, sobretudo) remonta a uma ideia de tradição; a temporalidade originária, associada ao passado americano imemorial, pré-colombiano, demarca uma tradição distinta, não europeia; e, por fim, a temporalidade da sociedade implantada é a síntese de ambas. Para o problema colocado por este artigo, é relevante reter que a temporalidade das sociedades implantadas revela mais do que o resultado do "encontro": por ser a expressão das tradições africanas, indígenas e europeias, a temporalidade da sociedade implantada alude ao porvir, ao futuro presente de uma América intercultural (THEODORO,1992).

Ao lado dos historiadores, os ensaístas registram essa temporalidade múltipla: Octávio Paz (1992, p. 83), quando anota que "debaixo das formas ocidentais ainda palpitam as antigas crenças e costumes", refere-se à sociedade implantada. Carlos Fuentes, por sua vez, usa a metáfora da dor do parto para anunciar a temporalidade hispânica: "É com uma dor magnífica que se funda a relação da Ibéria com o Novo Mundo: um parto que se dá com o conhecimento de tudo aquilo que teve de morrer para que nós nascêssemos: o esplendor das antigas culturas indígenas" (FUENTES, 2001, p. 16). Mais adiante, a expressão do amálgama com a tradição hispânica se alicerça em um imaginário também múltiplo: "há muitas Espanhas em nossas mentes". Quando qualifica essas "muitas Espanhas”, o ensaísta registra a ambiguidade da metrópole, que é mãe compassiva e conquistadora cruel. Mais instigante do que esses registros temporais é a síntese elaborada um pouco mais adiante, no mesmo texto. Contrariando o

\footnotetext{
3 Em nossa compreensão, o termo "temporalidade" é válido desde que associemos "tempo" e "historicidade". Isso significa que o tempo não é uma evidência, uma naturalidade, mas sim experiência histórica. Determinar a temporalidade significa que, ao observar uma época específica, lhe concedemos inteligibilidade quando alcançamos sua forma particular de se relacionar com o tempo, considerando, simultaneamente, como tal coletividade lida com os rastros do passado no presente e como imagina (espera) seu futuro (KOSELLECK, 2006).
}

\section{GANPHLAC}

Revista Eletrônica da ANPHLAC, ISSN 1679-1061, No. 17, p. 59-86, jul./dez. 2014. http://revista.anphlac.org.br/ 
diagnóstico de um parto que anuncia a morte de uma tradição para o nascimento de outra, o ensaísta provoca: "o problema com os estereótipos nacionais, evidentemente, é que contêm uma semente da verdade, ainda que a constante repetição a tenha enterrado. Há de morrer a semente para que a planta germine?”. Mesmo que a referência seja à Espanha, a síntese ensaística é reveladora: a um só tempo, critica as histórias nacionais pelo que elas escondem e anuncia o que é escondido: a semente não morre para que a planta germine. A América híbrida é a expressão mais próxima de uma Espanha híbrida, uma vez que "nenhum outro país da Europa, com exceção da Rússia, foi invadido por tantas e tão diversas ondas migratórias" (FUENTES, 2001, p. 17).

Essa tripla relação temporal é indício da singularidade americana. Quando nos referimos à singularidade, alertamos que alcançar o conhecimento sobre qualquer fenômeno histórico implica reconhecer que, no tempo do próprio fenômeno, há uma ideia acerca dele, que é sempre estranha a nós. Essa ideia vai incorporando a mudança de outros tempos, o que nos conduz, simultaneamente, à incapacidade de alcançar o fenômeno puro - o que alcançamos é a história do mesmo (VEYNE, 2011). E é essa história produtora da historicidade que constitui um lugar, o lugar da experiência. Dessa maneira, narrativa e tempo ordenam uma experiência em um lugar, produzindo a relação entre o que dizem que somos, o que achamos que somos e o desejo de descobrirmos o que realmente somos. Explorar as narrativas sobre a América Latina exige dissecar suas temporalidades e as experiências que circulam no interior dessas mesmas temporalidades.

A narrativa sozinha não consegue preencher o vazio da explicação, pois, para além de enunciar, ela precisa experienciar. Quando se entende a narrativa como experiência, é possível afirmar que a literatura, o ensaio e a historiografia não são apenas produtos da cultura, mas sim a experiência histórica viva e pulsante de um lugar. ${ }^{4}$ Diante do exposto, a hipótese que guia este artigo é: as narrativas construídas

\footnotetext{
${ }^{4}$ Por exemplo, quando o poema Martín Fierro narra a experiência do gaúcho dos pampas, atribuindo-lhe os qualificativos de deserdado, solitário, bastardo, desamparado, fica evidente que a intenção não é apenas a de criticar a situação no campo e o discurso da civilização. No poema, a narrativa cumpre a função fundamental de reforçar uma imagem recorrente, a da América órfã - órfã de seus deuses, como na Conquista; órfã de seu Rei, como na invasão francesa e na independência que lhe seguiu. Essas imagens, nascidas da vida concreta, são capitalizadas pela narrativa, que reatualiza, em outro tempo, a experiência. Uma vez reatualizada, a narrativa passa a ser a expressão do lugar, exatamente como o poema de Hernandez se torna um expoente da literatura argentina e uma expressão do homem bravio do
}

\section{GANPHLAC}

Revista Eletrônica da ANPHLAC, ISSN 1679-1061, No. 17, p. 59-86, jul./dez. 2014. http://revista.anphlac.org.br/ 
sobre a América lhe conferem o lugar, sempre atualizado, da utopia; utopia entendida não como algo de impossível realização, mas exatamente como seu contrário, ou seja, como o vir a ser, como o que há de se realizar. Nesse sentido, ainda hoje, somos o Novo Mundo, não mais por uma relação hierárquica com a Europa, mas por uma incapacidade (autoatribuída também) de nos realizarmos como tradição - isso porque temos uma ideia consolidada sobre o que é tradição e essa está no Ocidente, o que empresta sentido à denominação cunhada por Alain Rouquié para se referir à América Latina, o "Extremo Ocidente" (1991). Essa narrativa conclusiva, como se constatará, pode ser valorada positiva ou negativamente. Por mais que desejemos - e esse desejo esteve presente em muitos manifestos culturais latino-americanos -, a tradição précolombiana não sustenta, por si só, o nosso reconhecimento interno. ${ }^{5}$

Do ponto de vista historiográfico, essa narrativa que apela à utopia se cristaliza em uma orientação que mantém a liberdade como meta, uma vez que os americanos não seriam livres. Carlos Fuentes (2001, p. 261) anota que "as revoluções [as da independência] foram animadas por um furor libertário”. Assim mesmo, ao contrário do desejo de suas lideranças, a independência não garantiu a liberdade; há que se produzir uma segunda independência - a liberdade, então, permanece como utopia, podendo ser reatualizada em inúmeros projetos. Para essa interpretação, que se afirmou ao longo do século XIX e manteve sua vitalidade, a América permanece presa às suas heranças malditas: a geografia e o clima inóspitos, a raça impura, a economia primária, as demandas do capital internacional que a colocam em posição periférica. Essa narrativa, particularmente no que se relaciona à questão racial, sustenta, também em uma

pampa. Assim o gaúcho é retratado, em uma das estrofes de Martín Fierro: "sua esperança é a coragem/sua guarda é a precaução/seu objetivo é a salvação/E ninguém lhe dedica desvelo/sem mais amparo do que o céu/nem outro amigo do que seu facão" (HERNANDÉZ, 1987, s/p.). A leitura desse trecho permite entender de que modo o sentido constitui uma imagem que tem poder duradouro porque associado à capacidade de atualização da imagem - é nessa capacidade que reside a força da narrativa.

${ }^{5}$ Octávio Paz valoriza a linhagem ocidental da América Latina. Para o autor, a sobrevivência das culturas passadas não impede essa inserção; antes, faz com que a inserção não se revele simplesmente uma imitação dos modelos europeus. Vale a citação: "O caso da América Latina é muito distinto do desses países [Índia, China e Japão]. Basta pensar que nós somos cristãos, falamos espanhol e português (duas línguas europeias) e fizemos nossa independência com ideias francesas e inglesas, isso para nos darmos conta do que nos afasta do Oriente. Certo, somos parte do Terceiro Mundo se pensarmos em termos econômicos e sociais: somos economias dependentes, pouco desenvolvidas e com imensos problemas sociais e políticos; entretanto, se pensarmos em termos históricos, somos parte da civilização do Ocidente. Vivemos em sua periferia. Dessa perspectiva, a visão de América Latina como um fragmento do Terceiro Mundo é simplista." (PAZ, 2010, p. 290)

\section{CANPHLAC}

Revista Eletrônica da ANPHLAC, ISSN 1679-1061, Nº. 17, p. 59-86, jul./dez. 2014. http://revista.anphlac.org.br/ 
temporalidade longa, o sentimento de infelicidade das elites americanas quanto ao seu nascimento extraeuropeu. ${ }^{6}$

A constituição de uma narrativa para a América, conforme já anunciado, foi tarefa importante para os ensaístas do século XIX, que tomaram o processo das independências como um marco fundador. A experiência desse evento produziria uma narrativa, a ser valorada de acordo com a utopia já referida. Retomaremos essa questão logo adiante para explorar um terceiro objetivo deste texto: relacionar a história latinoamericana ao trauma, tentando explicitar por meio de quais operações narrativas (muito presentes nos ensaios) se qualifica o caminho histórico da América como acidentado, fraturado. O trauma, para a abordagem proposta, deve ser compreendido como uma lesão que é valorada afetiva e moralmente, constituindo uma narrativa dos americanos sobre a América. Ao incorporar essa narrativa, o trauma é permanente, ou seja, a narrativa não pretende se liberar da ferida, mas reelaborá-la. É importante ressaltar que nos referimos a um trauma coletivo: ele aparece na escrita da história das Américas, requerendo a empatia dos sujeitos partícipes dessa cultura. O trauma encontra (e integra) os termos que tratam de significar a história latino-americana, por isso conquista, colonização e independência são expressões que fazem mais do que identificar blocos de tempo.

Quando se remete aos trezentos anos de espoliação (expressão muito comum nos manifestos, durante as independências) para demarcar a experiência temporal da conquista e da colonização, o tempo longo é propositalmente espremido em bloco para que a experiência assuma a feição da opressão. Nesse bloco espremido, espoliação, violência e genocídio integram a narrativa, que, por meio de sinais linguísticos, desvela a experiência - vale lembrar que nomear equivale a tomar posse (TODOROV, 1993). A força do signo revela mais do que o acontecimento, revela o que conseguimos apreender

\footnotetext{
${ }^{6}$ Essa seria uma das fatalidades impossíveis de serem evitadas, como alertava Simón Bolívar: "A América inteira está cheia de escravos e indígenas cativos: os poucos europeus que deixaram filhos neste solo dividido combinaram tanto sua raça que tudo é diferença, oposição e ódio. Nós, mais do que os outros americanos, padecemos dessas doenças e por isso mesmo devemos buscar algo específico [a cura] por meio de um medo externo. O remédio é custoso e talvez seja um cáustico cruel, mas ele evitará a gangrena que nos cobrirá dos pés à cabeça. Você pode consultar, meditar e aplicar essa interpretação, se for aprovada pelos conselheiros do governo. Também acrescento que a apresente como minha porque não acho inconveniente expressá-la publicamente". (Carta para Francisco de Paula Santander. Quito, 30/01/1823. Tomo III, R. 918, p. 344. Original. In: LECUNA, 1965).
}

\section{GANPHLAC}

Revista Eletrônica da ANPHLAC, ISSN 1679-1061, Nº. 17, p. 59-86, jul./dez. 2014. http://revista.anphlac.org.br/ 
dele, produzindo experiência. Assim, a narrativa cumpre dupla função: reelabora o trauma passado, expressando a experiência de outrora, e propõe a experiência do porvir. Então, pensar o trauma conduz a interrogar palavras que se encontram articuladas em uma narrativa pretensamente ordenada. São elas: labirinto, desamparo, orfandade, desencanto, desalento, solidão e liberdade. Essas palavras emprestam coesão a uma narrativa que é interna à América - faz parte de como ela captura sua experiência no mundo - e uma que lhe é externa - faz parte do que o mundo lhe diz sobre sua própria existência.

Colocando lado a lado essas duas formas de construção narrativa sobre um lugar, a identidade latino-americana nasceria do trauma, especialmente manifesto na recorrência em apontar a contradição à memória do sistema colonial (MARTINS, 2004). Por sua vez, a ideia de colônia se dilata na experiência do colonizado; dela se ocupa também o tempo longo, daí a ojeriza hispano-americana ao imperialismo sentido duramente como colonização, muito antes das experiências das vanguardas políticas no século XX. Desse modo, o trauma segue sendo como tudo mais na América, responsabilizando-se pela reatualização da utopia. Elaborado afetivamente em nossas produções culturais mais caras, o trauma não se rende à cura, mas à imaginação profícua dos latino-americanos.

\section{As independências: liberdade, desamparo e utopia}

A palavra-síntese das independências é a liberdade, liberdade que se deve conquistar em situação de desamparo e orfandade - a Espanha fora invadida por Napoleão em 1808 e a América se viu sem Rei. A ruptura com a Espanha não foi decidida na primeira hora da invasão francesa. É certo que o descontentamento criollo existia, mas também é certo que muitos preferiam não se lançar a um empreendimento inaudito, capaz de despertar forças revolucionárias inesperadas. Dessa maneira, avaliar as independências e compreender de que modo suas narrativas reatualizam o trauma é ter em vista a complexidade dessa experiência. Não há uma narrativa, há várias. Todavia, uma delas é emblemática e tem como seu construtor a principal liderança das independências na América do Sul: referimo-nos a Simón Bolívar. As análises de Simón Bolívar sobre a América revelam uma linha contínua, ao mesmo tempo

\section{GANPHLAC}

Revista Eletrônica da ANPHLAC, ISSN 1679-1061, Nº. 17, p. 59-86, jul./dez. 2014. http://revista.anphlac.org.br/ 
descendente. Suas previsões oscilaram do entusiasmo e da convicção à amargura e ao desencanto. Esse caminhar, nada progressivo da perspectiva da experiência, foi incorporado pela historiografia, contribuindo para que se assentassem preconceitos em torno dos projetos para o continente. Para uma corrente historiográfica tradicional, a "América seria ingovernável" e os projetos políticos modernos não fariam mais do que “arar no mar".

Libertar exige também o patrocínio e a garantia da liberdade; para tanto, Bolívar teria de impor aos territórios libertos uma ordem administrativa. Porém, em meio à guerra, não lhe coube o governo das repúblicas. Bolívar insistiu em subjetivar-se como guerreiro, exatamente, porque se preocupava em romper o laço com a Espanha. Seu mundo era o da guerra e, embora pensasse em alternativas políticas para o ordenamento e a administração das repúblicas, não se impunha essa tarefa. Para o leitor atento, Bolívar construiu-se a partir da crença absoluta na liberdade, que significou para ele um ideal demiurgo (PRADO, 1981). Finda a guerra, ele se tornou o general em seu labirinto, parafraseando García Márquez. Isso porque, no momento em que Bolívar percebeu que a liberdade não conseguiria resolver os problemas colocados à América, sentiu-se traído em suas convicções e em seus afetos. Era o momento de pressagiar que a liberdade tinha se destituído do seu poder transformador.

Ao ler os escritos de Bolívar, identificamos, de novo, o trauma, dessa vez relacionado à ruptura profunda provocada pela Independência. A essa ruptura se associam o desencanto com a própria obra e a emergência de um cenário político novo, que relegava o primeiro cidadão da pátria à solidão. Há uma era de ouro e esta se encontra nas três primeiras décadas do século XIX. Para que essa operação narrativa funcione, a guerra e seus estragos precisam ser matizados, daí a liberdade assume o lugar central - mas essa é uma liberdade tutelada, não plenamente republicana e que mantém o herói porque não suporta o desamparo. O herói precisa estar a postos no Panteão para que a utopia reelabore o trauma: a reelaboração não significará o desaparecimento da sensação de desamparo. Entretanto, essa sensação será substituída pela possibilidade de colocar em andamento novos projetos em nome da liberdade tão almejada.

$\mathrm{O}$ afastamento entre as independências e a liberdade esteve manifesto na narrativa americana por meio do argumento que reforçava a importação de modelos e a

\section{GANPHLAC}

Revista Eletrônica da ANPHLAC, ISSN 1679-1061, Nº. 17, p. 59-86, jul./dez. 2014. http://revista.anphlac.org.br/ 
incapacidade de efetivar o liberalismo e a sua receita civilizatória nos trópicos. Nessa concepção, as independências não afirmaram a modernidade, posto que as elites criollas, contrariamente, se consolidaram como "herdeiras" da ordem espanhola. Assim, "a novidade das novas nações hispano-americanas é enganosa; na verdade, trata-se de sociedades em decadência ou em forçada imobilidade, sobrevivências e fragmentos de um todo desfeito" (PAZ, 2010, p. 16). O que esse tipo de interpretação registra é que $o$ discurso é vazio de prática; os latino-americanos, então, se "movem na mentira com naturalidade", na medida em que "durante mais de cem anos vivem regimes de força, a serviço de oligarquias feudais, mas que utilizam a linguagem da liberdade" (PAZ, 2010, p. 16).

A historiografia mais recente inverte essa premissa. Mary Louise Pratt (1999) anota que as elites no Novo Mundo eram desafiadas pelo movimento e pela experimentação social. Nesse caminhar, os modelos metropolitanos não ofereciam recursos suficientes para atuar naquele contexto. Há uma inovação sem precedentes, a começar pela invenção das próprias elites como cidadãs da América republicana. No mínimo, se a prática oligárquica não se transformara no todo, ela se via cindida pelo desejo de partilhar com o mundo uma nova linguagem. Entretanto, no meio do caminho estava o "povo", “inculto, incivilizado e indomável". Diante deste, para onde levariam os desvarios da liberdade? Essa hesitação conduziria ao combate armado e intelectual, fazendo com que a América Hispânica assistisse ao nascimento de, respectivamente, generais republicanos e ensaístas paradigmáticos.

Também representante expressiva da historiografia recente, Hilda Sábato (2008) chama a atenção para os variados liberalismos. Anota que, durante muito tempo, liberalismo e modernidade foram encarados como um par indissociável, o que conduzia à crítica quanto à implantação do primeiro nos trópicos. Essa crítica era comum tanto a atores históricos quanto aos analistas que se seguiram. Dessa forma, o liberalismo foi fixado como uma "planta exótica" na América. O que queremos registrar com isso? Que, para a América, o fracasso da República era o fracasso do liberalismo. Essa era a retórica mais aparente por parte dos atores históricos, desde o século XIX, e essa retórica foi confirmada por uma extensa literatura. Assim, em síntese: o liberalismo e a República eram inviáveis, e a modernidade, inalcançável. Não se experimentou pensar o "novo" sobre a vivência republicana, estabelecendo a desambiguação entre república,

\section{GANPHLAC}

Revista Eletrônica da ANPHLAC, ISSN 1679-1061, Nº. 17, p. 59-86, jul./dez. 2014. http://revista.anphlac.org.br/ 
liberalismo e modernidade; manteve-se a Europa como contraponto. As relações entre liberdade e independências, que vêm sendo revisitadas pela historiografia, alimentaram os ensaios nas décadas de formação do espaço nacional.

\section{O ensaio como ordenador do projeto nacional oitocentista}

Conforme anunciado, o ensaio é considerado um gênero fundador no que concerne à escritura sobre a América Latina, desde o século XIX, sendo localizado como um emergente discursivo dos processos revolucionários. Os ensaios refletiam sobre a magnitude da tarefa empreendida pelos americanos, delimitando um espaço por onde o gênero ensaístico por muito tempo transitaria, conectando política e discurso. Em um período em que "se podia ver a história acontecer, as turbulentas décadas a cavalo" (SÁBATO, 2008, p. 311), a América construiu suas repúblicas, aliando as armas à palavra, como fundamento para a luta por autonomia e para forjar nações.

As abordagens e as soluções apontadas para a "regeneração" dos povos na América Hispânica foram distintas. Dessas distinções emerge a figura do labirinto, pois os signos de outrora perpassam a historiografia sobre o continente, num processo contraditório de resistência e fragmentação. Há um tipo de escrita na América Latina modeladora de uma narrativa que valoriza mais a ensaística do que a história propriamente dita. ${ }^{7}$ Essa escritura, assim constituída, seria um "vício de origem" que contribuiria para a pouca sistematização e reverberação das reflexões historiográficas no continente. Não por acaso, Francisco Bilbao sentencia em El evangelio americano (1864, p. 28, grifo do autor): "Uma das grandes diferenças que caracteriza o espírito, o engenho é o modo de raciocinar e de sentir do homem Americano digno desse nome, É SUA REBELIÃO CONTRA A HISTÓRIA”.

Ciente do confronto entre os atores históricos e seus intérpretes, a narrativa ensaística - e a historiografia, mais tarde - pontuou a "vocação" da América Latina

\footnotetext{
${ }^{7}$ Nesse sentido, Irlemar Chiampi Cortez (1979, p. 160), ao refletir sobre o discurso americanista dos anos 1920, reitera que a história das ideias no subcontinente tem mostrado que "a combinação do humanismo idealista e o caráter historicista e pragmático tem levado a inteligência hispano-americana a um modo singular de assimilação e deformação das ideias importadas". Em virtude disso, os temas americanos seriam tratados em perspectiva antidocumental, voltada para "uma dimensão profunda do ser histórico" da América - os ensaios traduzem essa concepção.
}

\section{CANPHLAC}

Revista Eletrônica da ANPHLAC, ISSN 1679-1061, Nº. 17, p. 59-86, jul./dez. 2014. http://revista.anphlac.org.br/ 
como portadora de uma identidade que lhe era negada externamente. Daí apelar à independência como recorrente ponto de partida, visando a instituir o elo perdido da nacionalidade. Pode-se criticar o estabelecimento da mística nacional, uma vez que ele redundou numa operação excludente por meio da qual a elite criolla impôs-se como a portadora de uma razão histórica (RÜSEN, 2001). Entretanto, de modo algum se pode obliterar a historicidade dessa tarefa e o desejo de demarcar um lugar referencial para a América por meio de textos fundadores. Quando se trata de avaliar essa escritura, não é possível perder de vista o fato de os ensaios constituírem um projeto identitário e de memória: era fundamental fazer e escrever a história das comunidades nacionais, emergentes do processo de emancipação. Em busca de um lugar para a América, os ensaios transpuseram a tradição, disseminando-a no discurso dos atores históricos daquele tempo e dos tempos vindouros. Em virtude disso, essa tradição e seus elementos narrativos foram acolhidos pelos ensaios do século $\mathrm{XX}$, tal como se constata pela leitura de Octávio Paz e Carlos Fuentes. Torna-se fulcral compreender os caminhos que levaram as construções nacionais a se impor com tamanha força narrativa na pena dos ensaístas, os quais se arrogaram o papel de intérpretes e fundadores da tradição. Como anunciado, para as considerações sobre o século XIX, nos ativemos aos ensaios do chileno Francisco Bilbao (1823-1865) e do mexicano Justo Sierra (1848-1912).

Amparada no dualismo presente nas análises clássicas do período, a obra de Bilbao é atravessada pela contraposição entre Europa e América. Críticas contundentes à colonização espanhola foram por ele proferidas, o que ratifica a presença de uma perspectiva mais radical dos letrados nas regiões periféricas, conforme a antiga organização hispânica. Esse autor também criticou as concepções de progresso e civilização caras às elites e condenou o que denominou de falácia da civilização, quando os franceses invadiram o México, ação que, segundo ele, fez retroceder a dignidade e a fraternidade universais. Para o ensaísta, a solução não era colocar-se sob a guarda da "França civilizada", como muitos advogavam, mas sim buscar a unidade latinoamericana. Reiterava a urgência em se elaborar um evangelho americano, pautado na autonomia e respeito entre os povos, pois o modelo difundido da civilização europeia constituía-se na "doutrina da escravidão do mais fraco pelo mais forte e pelo despotismo" (BILBAO, 1864). Alertava os americanos quanto ao "grosseiro sofisma da

\section{GANPHLAC}

Revista Eletrônica da ANPHLAC, ISSN 1679-1061, Nº. 17, p. 59-86, jul./dez. 2014. http://revista.anphlac.org.br/ 
Europa”, assentado numa ideia de civilização que não via contrariedade ou paradoxo em propugnar a morte e a exclusão. ${ }^{8}$

Embasado nas premissas anunciadas, o chileno propunha a superação do passado colonial, em termos políticos e espirituais, muito embora essa superação não devesse significar um rompimento com a tradição histórica anterior. Observemos que o trauma da colonização é identificado e reelaborado, permitindo inclusive a associação com a metrópole - o que não parece muito distante da ambiguidade anunciada por Fuentes (2001, p. 17), quando qualifica a Espanha como mãe compassiva e conquistadora cruel. A superação da herança colonial, profundamente arraigada nos espíritos, seria alcançada com o ensino da "ciência republicana" ao povo, eliminando a "herança maléfica" (o resquício colonial). Diferentemente de outros autores do período, sua concepção de povo incorporava os mestiços e os índios, ao mesmo tempo em que conclamava as elites políticas a pensar em formas efetivas de inclusão social das camadas subalternizadas. Para Bilbao, a reelaboração deveria se dar mediante o reconhecimento de uma tradição histórica - também hispânica - que não tinha como ser abandonada. A Espanha, identificada com a colonização, não deixava de ter o reconhecimento como instituidora dos laços entre Europa e América. A síntese é um paradoxo: a proposta de rompimento com a herança colonial mantinha aberta a cicatriz, na medida em que esta reconstituía uma tradição histórica, ocidental e hispânica.

Em contraposição, Justo Sierra elabora uma narrativa fatalista sobre a sociedade mexicana pós-independência, atribuindo ao governo responsabilidade pelo desencontro por tentar congregar uma mescla de raças inapta à República. Assim, para esse autor, a ideia de trauma é imanente: além dos graves problemas internos, que prolongaram as lutas fratricidas por várias décadas após a independência, o México sofrera com a interferência externa direta como nenhum outro país da América Hispânica, na mesma

\footnotetext{
${ }^{8}$ Ortega y Gasset (1993, p. 107-108) reverberou esse tipo de análise. Para ele, a desintegração vivida no interior da Espanha implicou que as províncias ultramarinas dela se separassem, fazendo com que seu corpo espacial voltasse, então, à sua nativa nudez peninsular. Como o primeiro século de unidade peninsular coincidiu com a colonização americana, essa foi absorvida pela conquista, que, para os espanhóis, se constituiu apenas em seu prelúdio. A colonização teria sido o único fato significativo que a Espanha empreendera, coisa peregrina. O povo espanhol, sem propósitos conscientes, sem tática deliberada, engendrou outros povos. A grandeza e a miséria da colonização advieram desse fato. Para o autor, o povo espanhol fez tudo o que tinha a fazer: povoou, cultivou, cantou, lamentou, amou. Porém, não podia dar às nações que engendrava o que não tinha: disciplina superior, cultura vivaz, civilização progressiva.
}

\section{GANPHLAC}

Revista Eletrônica da ANPHLAC, ISSN 1679-1061, Nº. 17, p. 59-86, jul./dez. 2014. http://revista.anphlac.org.br/ 
ordem e intensidade. Em seu ensaio Evolución política del pueblo mexicano, a fusão das raças no México era vista como inexorável, e o mestiço seria o tipo nacional por excelência. No caso dos indígenas, a situação era avaliada por ele distintamente: para serem incorporados ao progresso, teriam que ser preparados pela educação, que ampliaria o contato com os outros segmentos.

Diferentemente de Bilbao, Sierra não elaborou críticas sistemáticas à colonização em função da centralidade e importância da Nova Espanha no espaço colonial, o que não o impediu de apontar problemas. Destacou que, no México, dadas as características e o número dos grupos indígenas, não foi possível alijá-los do processo civilizador espanhol, o que distinguiu a formação nacional mexicana. Sierra - assim como Paz incorporaria no século XX - considerava os espanhóis da conquista como homens de cobiça ilimitada, porém heroicos. Se os filhos de Malinche emergem como símbolo da pátria mestiça e violada na pena de Octavio Paz, Sierra assinala que os mexicanos nascem como filhos de dois povos e de duas raças emergentes da conquista: suas raízes estavam na terra que habitavam os povos aborígenes e no solo espanhol. Para o ensaísta, esse fato dominaria a história do México, renascido como nação que adotou orgulhosa o nome de uma tribo indígena, os mexicas. Em virtude disso, ao cabo de três séculos, a Espanha havia engendrado "Espanhas americanas", que almejavam viver por conta própria. Contudo, ao desejo legítimo de se emancipar não foi agregada a capacidade para o autogoverno, e o México esteve a ponto de perder sua autonomia "no cipoal interminável das lutas civis, do espírito de aventura, próprio da raça de que provinha" (SIERRA, 1986, p. 117).

Como reiterado em diversas passagens deste artigo, no século XIX consolida-se um esforço fundador republicano, criando um campo de experimentação profícuo para projetos díspares. A pretensão desses ensaístas era de que a República fosse conformada por um conjunto de práticas discursivas que consolidariam a identidade e apontariam o caminho para a redenção definitiva. Não há como duvidar do esforço pragmático e intervencionista dos letrados. Todavia, não deixa de ser interessante que a pragmática adotada seja uma escolha político-cultural, na medida em que

a construção da nação realizada por determinados textos, ou discursos, ou por determinados sujeitos sociais, é passível de ser substituída por

\section{GANPHLAC}

Revista Eletrônica da ANPHLAC, ISSN 1679-1061, Nº. 17, p. 59-86, jul./dez. 2014. http://revista.anphlac.org.br/ 
outras e implica, de fato, uma leitura incompleta e parcial; ou seja, inesgotável". (ACHUGAR, 2006, p. 231)

Compreender o universo desses ensaístas é, sobretudo, apreender como recorreram à memória para reforçar uma construção pátria. Por meio de uma operação ensaística e historiográfica, entrelaçaram passado, presente e futuro em seus escritos, perspectivados por um projeto fundamentado na hierarquização social. Esses letrados se preocupavam em admoestar seus coetâneos, apontando-lhes um dever nacional: resolver a traumática questão racial, unificando "elementos nacionais dispersos". Como o esforço era pragmático e intervencionista, os ensaístas apontavam a doença, prescrevendo-lhe tratamento: a nação liberta emergiria do conhecimento, da educação universal e da moral.

Apesar dos localismos, decorrentes do isolamento estabelecido pela organização político-administrativa da Coroa Espanhola, as ideias de separação, veiculadas nos ensaios, agenciaram projetos que superaram as barreiras territoriais. Os ensaístas, ao assumir a utopia da unidade, convocando do Panteão os heróis da independência, foram, em boa medida, responsáveis pelo referendo de uma nação homogênea. O desejo de que ela realmente assim o fosse, contrastado com a impossibilidade de uma República racialmente apaziguada, tornou o trauma recalcado. Essa permanência sustentou os ensaístas do século XX e alimentou os movimentos sociais contemporâneos (do indigenismo no século XIX a Chiapas no século XX). A trajetória da formação nacional e da intervenção ensaística reforça as assertivas de Hilda Sábato e Mary Louise Pratt: a difícil aprendizagem política efetivou uma transição inaudita para a República, que não pode ser compreendida sem a desambiguação entre a experiência moderna americana e os modelos políticos europeus.

\section{Da atualização dos referenciais culturais americanos no ensaísmo}

Após a leitura dos ensaios oitocentistas, constatamos sua contribuição a uma peculiar construção historiográfica e a um pensamento social, que se mantiveram vigorosos durante o século XX. Assim, a tônica deste artigo não se relaciona apenas às identidades constituídas por meio da narrativa diretiva e disciplinadora dos ensaios, mas

\section{GANPHLAC}

Revista Eletrônica da ANPHLAC, ISSN 1679-1061, Nº. 17, p. 59-86, jul./dez. 2014. http://revista.anphlac.org.br/ 
à circulação, apropriação e transformação de ideias. Destacamos ensaios de autores considerados paradigmáticos, quando se trata de pensar a conformação da nação na América Espanhola do século XIX. Eles foram protagonistas de seu tempo, e mesmo Francisco Bilbao, apesar de não ter conquistado espaço político de destaque em decorrência de sua crítica corrosiva à herança colonial ibero-católica, teve influência intelectual significativa no século $\mathrm{XX}$. Os ensaios foram utilizados também pelas autoridades políticas como um meio de disciplinamento da população, que deveria ser homogeneizada por dispositivos convincentes e de ampla divulgação. Partilhava-se da compreensão de que apenas uma pedagogia nacionalista seria capaz de formar cidadãos que acatassem voluntariamente as novas formulações republicanas.

Os autores examinados apelaram aos sentimentos que pretendiam cultivar nos atores das novas repúblicas, engajando-se em um projeto para a conversão dos americanos, de súditos a cidadãos livres. Liberdade então significava novas possibilidades de expressão nos marcos de respeito aos direitos do cidadão, em uma modernidade mesmo que ambígua. A tarefa se tornava mais ingente na medida em que as ideias modernizantes iam de encontro à imprecisão dos ideais e das expectativas populares. Justo Sierra evocou de forma recorrente essa questão nas décadas em que o México foi dilacerado pela guerra civil, sem que se consolidasse o ideal republicano. Diante desses antagonismos, essa vanguarda de letrados adjudicava a capacidade de apontar os rumos da história, por meio do ensaio, buscando intervir nessa mesma história, a fim de superar o cenário nacional caótico para alcançar a paz e o progresso. A maturidade histórica se apresentava com nomes distintos, tais como desenvolvimento, progresso, sociedade igualitária. Sobretudo, uma identidade unívoca era a bandeira agregadora.

Substituir os modelos representativos da monarquia espanhola pelo governo local, referendado pelo povo, e construir "a" nação eram as tarefas a que se propunham esses homens. Não obstante encontremos certa similaridade em muitos dos argumentos referendados pelos autores, é preciso atentar para o fato de que os debates políticos e intelectuais do período formativo das nações no continente endossaram distintas perspectivas, que, por sua vez, conduziram a projetos políticos divergentes, cristalizando a figura do mosaico político e cultural na região. Exatamente por isso, a historiografia contemporânea aponta que não é simples enquadrar os espaços 
americanos pelas denominações "liberalismo" e "conservadorismo". Os princípios que embasaram os grupos políticos, frequentados comumente pelos intelectuais ensaístas, não cabem nessas denominações "consagradas" por tanto tempo.

Dissonante em relação à historiografia tradicional é a constatação de que esses letrados não produziram uma simples cópia do pensamento europeu, avançando para além da simples propositura de uma identidade nacional. Essa postura sinaliza uma peculiaridade dos ensaístas da América Hispânica, responsáveis por criticar as nações colonizadoras. Enfim, admiração não significava ausência de crítica. Em face da aferrada fidelidade à figura do rei durante todo o período colonial e que se prolongou nos dois primeiros anos da invasão francesa à Espanha, o hispanismo foi se interpondo nas reflexões, produzindo resultados dissonantes, mas absolutamente inéditos. O ensaio, espaço aberto e profícuo à dissonância, ostentou uma reflexão subversiva do resistente paradigma historiográfico da mera imitação.

$\mathrm{Na}$ busca por modelos que diferenciassem a região da tradição hispânica, a análise de Guerra (2006) torna-se ainda mais pertinente. Esse autor destaca como resultado das guerras de libertação o surgimento de Estados no sentido de comunidades políticas independentes, mas não ainda modernos. Para ele, desse processo surgiram comunidades soberanas, mas não nações modernas em seus atributos (um território, um sentimento de pertencimento, a partilha de um imaginário sobre o passado e de um projeto para o futuro). Essa concepção aparece claramente nos ensaios de Sierra, expressa como lamúria e fatalismo. Reiterava o ensaísta que a "nação imaginada" era então um projeto e um problema diante dos diversos fracassos. Para ele, a identidade comum, profundamente operativa durante as lutas de independência, não alcançou expressão política concreta, capaz de amalgamar a homogeneização identitária nas nações pelas quais tanto se lutou. Na pena desse ensaísta, o México ainda servia a uma utopia.

Para François Hartog (1996), na escrita desses autores oitocentistas, perpassava a estreita associação entre progresso e nação: nação como progresso e história como progresso da nação. Como a História era entendida como processo e o tempo se direcionava à progressão, não alcançar o fim desejado era um problema. Ao se configurar o impasse, esses autores atribuíam-se a função de apontar alternativas ao labirinto americano. Diante disso, não há dúvida quanto ao esforço propositivo dos

\section{GANPHLAC}

Revista Eletrônica da ANPHLAC, ISSN 1679-1061, Nº. 17, p. 59-86, jul./dez. 2014. http://revista.anphlac.org.br/ 
ensaios. Se essa escritura peculiar se mune de metáforas e constitui-se de criatividade, imaginação e utopia, nenhum desses elementos permite a conclusão da ausência de sentido e proposição. Essa perspectiva estava no horizonte de expectativa desses autores, mesmo que a ideia de progresso defendida entre eles fosse distinta.

Para os ensaístas, as repúblicas hispânicas tinham em seu horizonte muitos problemas a resolver, e sua mais urgente tarefa era reelaborar a herança traumática da colonização. O aprendizado republicano devia significar o norte mais acertado para tal reelaboração. Se, de um lado, a Espanha não escapava à crítica, do outro, as muitas "Espanhas americanas" referendavam a mãe compassiva e conquistadora cruel. A aposta das elites criollas esteve turvada pela experiência revolucionária. Foi a experiência revolucionária das independências que maculou a positividade da autonomia irrestrita. A república possível tornou-se tutelada, e a revolução, afastada da experiência e filtrada pela narrativa, reaparece, no século XX.

\section{Reatualizando o trauma}

As reelaborações do trauma não se esgotam. A experiência com as revoluções e os regimes militares no século XX reabrem feridas. Nesse sentido, comecemos por delimitar um marco: a Revolução Cubana trouxe à América Latina esperanças e expectativas de uma mudança profunda na economia e na sociedade de regiões então consideradas periféricas. Essas esperanças e expectativas foram partilhadas pelos países latino-americanos sobretudo, mas não apenas por eles. Apesar das críticas que logo viriam à organização do poder na Ilha, é certo que o impacto da Revolução Cubana não pode ser desprezado; o isolamento que lhe foi dirigido por Washington só fez reforçar a legitimidade da Revolução Cubana aos olhos dos países classificados como de "Terceiro Mundo" - e aos de todos aqueles que se sentiam comprometidos com o Terceiro Mundo. Nas palavras de Castañeda (1994, p. 58), que também se utiliza da retórica ensaística, "A solidão da ilha foi crucial para sua atitude em relação ao resto do continente. As atividades de Cuba no exterior fizeram da ilha humilhada pela Emenda Platt e pelos prostíbulos de Havana um ator no cenário mundial".

A ilha em solidão se comunicou com o mundo e tornou-se referência para a América Latina. No espaço de um artigo, é impossível discorrer, exaustivamente, sobre

\section{GANPHLAC}

Revista Eletrônica da ANPHLAC, ISSN 1679-1061, Nº. 17, p. 59-86, jul./dez. 2014. http://revista.anphlac.org.br/ 
a relação entre a perspectiva de "cubanização" do continente latino-americano e os golpes militares. Entretanto, é essencial compreender o movimento político regional (e global), impulsionado pela Revolução Cubana: os golpes militares não seriam apenas uma resposta à ousadia política daqueles que, esperançosos, espalhavam as expectativas de revolução; eles seriam uma tentativa de limpar do continente a memória de tais expectativas. Esse desejo foi conseguido quase integralmente, por um tempo: para tanto, restou a Cuba o isolamento e a solidão. Daí advém o trauma para o qual a solidão se torna signo: não havia acordo possível entre as subjetividades revolucionárias e as doutrinas de segurança nacional. Nos tortuosos caminhos da política, outra revolução veio ao encontro da cubana: a Revolução Chilena. Levando em consideração o caráter paradigmático da primeira das revoluções, é preciso admitir, porém, que a "via chilena ao socialismo", embora demonstrasse profunda solidariedade à Cuba de Fidel, se propunha (e se assumia) como distinta, na tática e na estratégia (AGGIO, 2003). Por esse motivo, o Chile é a expressão mais vigorosa da permanência do trauma - o que não implica dizer que o trauma não integre as narrativas argentinas, brasileiras, peruanas, dentre outras.

A reabertura das feridas latino-americanas no século XX poderia ser apresentada como premissa geral para as experiências das décadas de 1960 e 1970, na América do Sul. Entretanto, para não incorrer nessa generalidade e reafirmar o já exposto até este momento, examinaremos somente duas narrativas: o ensaio do cientista político Tomás Moulian, Chile actual (1998), que trata da experiência chilena e da ditadura pinochetista; e o discurso de Gabriel García Márquez, proferido em 1982, por ocasião da cerimônia de entrega do Nobel de Literatura. Enquanto Moulian expressa veementemente o trauma chileno, o discurso de Gabriel García Márquez retoma algumas utopias, que foram objeto da narrativa ensaística do século XIX. Dessa maneira, o argumento deste artigo fecha-se em círculo: o trauma reatualizado é convidado pela utopia para propor o próximo cenário à região.

Para Tomás Moulian (1998, p. 9), o "ensaio aporta ar e luz no clima monótono da escritura sociológica". Esse autor chileno não tem nenhum problema em assumir o estilo ensaístico, posto que não é de seu interesse "nem a coerência absoluta, nem a demonstração formal de cada hipótese", mas a insinuação capaz de modificar as estruturas de pensamento (MOULIAN, 1998, p. 10). Desde já, reiteramos: se o trauma 
não permite representação convencional, o ensaio é mesmo o melhor lugar para abrigálo, na medida em que essa escritura admite a linguagem fraturada e a metáfora inalcançável pela razão, mas profundamente identificada à experiência, cuja carga sensorial transforma vidas e transmuta caminhos. Apenas a escritura ensaística permite integrar a dor infligida pelo tratamento animalesco da tortura; diante da desumanização, a linguagem trivial a nada atribui sentido. Nesse campo aberto, o ensaio tem muito a dizer, pois, como vimos ressaltando, não faz do trauma uma patologia a ser curada, mas a reelabora.

Um golpe que utiliza força bélica para bombardear um palácio no meio da cidade e que leva à morte de um presidente ${ }^{9}$ não pode ser considerado menos do que traumático - esse foi o caso do golpe militar chileno. Naquele lugar, o golpe tem, ainda hoje, duas faces: primeiro, a da Junta Militar, memorável na imagem assustadora retida pelas lentes do fotógrafo holandês Chass Gerresten; e, segundo, a do General Augusto Pinochet Ugarte. Por que tamanha violência? Porque sua função era apagar quaisquer expectativas sobre a revolução chilena, que se pretendia distinta das experiências anteriores, tal como expressa Allende: "No Chile, as receitas 'reformistas' e 'desenvolvimentistas' que a Aliança para o Progresso impulsionou e o governo Frei promoveu não trouxeram alteração importante" (PROGRAMA DE GOVERNO, 1970, p. 90). A mudança, que àquele contexto assumia um tom categórico, dividiu a sociedade chilena, bem antes de dividir os grupos de esquerda que a apoiavam. No momento do

\footnotetext{
${ }^{9}$ Por quase quarenta anos, a morte do presidente Salvador Allende foi motivo de disputa, integrando, de acordo com Gonzalo Cáceres e Alcàzar Garrido (2005), o conjunto de mitos criados acerca do Chile da Unidade Popular. A violência do golpe, imediatamente, levou à solidariedade internacional - o Chile tornava-se a "central da derrota de um projeto humanista". Para a esquerda vencida, Allende começa a ser "desculpado" pelo desfecho de seu governo. Imolado no La Moneda, o presidente encarnaria, em que pesem os esforços do regime militar por meio de uma guerra comunicativa, toda a tradição republicana chilena, assentada na institucionalidade, na legalidade e na constitucionalidade - mitos também e que, de acordo com Tomás Moulian, fizeram com que os chilenos se esquecessem de seu passado de fúria, definindo-se como o exemplo democrático em meio a uma América conflituosa. A versão "expiatória" sobre Allende e seu governo omite a profundidade da crise institucional chilena, que se tornava, desde os primeiros momentos de 1970, cada vez mais massiva. Em face do combate com a figura de Allende, o governo militar não teve dúvidas: do mesmo modo, a repressão teria de ser exemplar - mais massiva do que seletiva -, e um projeto total deveria romper definitivamente com o passado chileno. Disso decorre a adoção da "racionalidade capitalista", cujo objetivo era destruir qualquer relação entre "desenvolvimento" e "democracia". Enfim, voltando às circunstâncias da morte do presidente, com o golpe efetivado, reconhecer o suicídio era se perguntar sobre a inabilidade política de Allende e da Unidade Popular. Não havia tempo e espaço para tal, era preciso à abalada resistência política ao regime militar se apegar em algo para entrever algum futuro. Apenas em 2011, o suicídio passou a constar como a causa da morte oficial de Salvador Allende.
}

\section{GANPHLAC}

Revista Eletrônica da ANPHLAC, ISSN 1679-1061, Nº. 17, p. 59-86, jul./dez. 2014. http://revista.anphlac.org.br/ 
golpe militar, "a sociedade estava saturada por expectativas paranoicas, ódios profundos, ansiedade compulsiva por uma resolução, sem se importar muito com por qual meio viria a solução" (MOULIAN, 1998, p. 168). Com retórica que apelava a mudanças profundas, a UP recebeu dos militares uma revolução invertida - depois daquele dia, 11 de setembro de 1973, o Chile nunca mais seria o mesmo. Cada qual ao seu modo, mas em conjunto, Allende e Pinochet encarnariam a ferida aberta da nação projetada por Francisco Bilbao. Não parece pouco anunciar, como o faz Julio Pinto Valejos (2013), que o processo desencadeado pela Unidade Popular, "de alguma maneira, situa-se na matriz da fundação do Chile que temos de viver hoje, e que foi objeto de curiosidades, temores e simpatias a nível continental e mundial" (2013, p. 32). Se a Unidade Popular é matriz do Chile contemporâneo, por que, então, não parece suscitar interesse para a historiografia chilena?

Há um silêncio incômodo da historiografia chilena em torno da breve experiência da Unidade Popular. Em um levantamento que se restringiu às obras de caráter historiográfico, Julio Pinto conclui que, transcorridas quatro décadas do golpe militar, o saldo da escrita histórica chilena sobre a Unidade Popular é de quinze obras não foram consideradas aquelas em que a Unidade Popular aparece como tema coadjuvante. A maior parte dessa escrita se fez presente na rememoração de trinta anos da queda da Unidade Popular, ou seja, é uma produção tardia e que emerge em uma circunstância catártica, quando à Unidade Popular é restituído o espaço público $\left(\right.$ PINTO, 2013) ${ }^{10}$. Mais do que constatar o silêncio historiográfico, interessantes são as hipóteses lançadas pelo historiador. Ao desclassificar a dor e a culpa como motivos para o silêncio, ao mesmo tempo em que aponta a vivacidade dos estudos sobre a ditadura de Pinochet e a independência (temas que remeteriam ao trauma, cujos sentimentos primeiros associam-se à dor e à culpa, em especial para a esquerda partícipe da Unidade Popular), Julio Pinto (2013, p. 39 ) indaga: “foram tão profundas as mudanças impostas pelo período ditatorial que os anos de Allende nos parecem inclusive mais remotos do

\footnotetext{
${ }^{10}$ Nas palavras do autor, "nosso levantamento bibliográfico produz um total de quinze obras (que poderiam se estender, com algo de generosidade, a 18), a maior parte delas publicadas nos doze últimos anos, por historiadoras e historiadores majoritariamente de esquerda e com uma forte concentração nos âmbitos da história política e social. Trata-se, em outras palavras, de um número bastante pequeno para um processo que tanto impacto teve em nossa história recente e que, além disso, deixou espaços temáticos importantes praticamente sem considerar". (PINTO, 2013, p. 3).
}

\section{GANPHLAC}

Revista Eletrônica da ANPHLAC, ISSN 1679-1061, Nº. 17, p. 59-86, jul./dez. 2014. http://revista.anphlac.org.br/ 
que a época da Independência, nestes dias, bastante mais estudada no Chile do que o lapso de 1970-1973?". Das constatações iniciais e da pergunta, retiramos um paradoxo: por um lado, parece não ser possível separar a experiência chilena e a ditadura pinochetista; por outro, não é possível conceder equivalência, no que concerne à relevância de uma e outra. Allende e a Unidade Popular, ao menos para a historiografia, permanecem na sombra, à sombra do poder transformador da ditadura de Pinochet.

Ainda seguindo as considerações de Julio Pinto, esse silêncio e a incapacidade de conceder um lugar equivalente, na historiografia, para a Unidade Popular vinculamse ao fato de ter se perdido um aspecto da experiência daqueles dias, o aspecto da festa. Lida e relida pelas lentes da derrota, a experiência chilena cristalizou-se como drama. Assim, a "sensação de abertura e protagonismo, de que não havia estruturas assentadas demais, nem obstáculos inalteráveis demais para parar a criatividade coletiva, o que imprimiu nesses mil dias seu selo mais eletrizante e mais entranhável” (MOULIAN, apud PINTO, 2013, p. 40), ficou perdida nas brumas do regime militar. Por que a história chilena não absorve a festa? Porque ela lê a experiência chilena a partir de fím, de seu "traumático desfecho, fazendo com que este passe a ocupar, como fator explicativo, um lugar central e decisivo em boa parte da literatura produzida sobre o período" (AGGIO, 2002, p. 27). Lida do lugar do trauma, não pode integrar a utopia (resumida no slogan avanzar sin transar). Contudo, é tempo de perguntar: é possível integrar a utopia (ou a festa)? Superando o medo, as mobilizações sociais da década de 1980, as protestas, tentaram retomar a festa, mas a transição chilena assumiu como projeto o que denominou por "ruptura pacífica", que apenas se configurou no momento em que a oposição reconheceu sua fragilidade e se pôs a discutir a mudança em um terreno institucional dominado pelo calendário do governo militar. Para viabilizar tal saída, enterrou o questionamento à Constituição de 1980, que instituíra o plebiscito de 1988 do qual se decidira participar. A utopia cedeu espaço ao realismo da transição.

No caso chileno, a impossibilidade de integrar a utopia não se vincula ao esquecimento da experiência ou do protagonismo de outrora (que, ao contrário, seguem como remordimientos muito vívidos), mas sim com a expectativa de futuro que acabou por ser validada pela transformação imposta pelo regime militar. O "sonho romântico de profetas desarmados" (MOULIAN, 1997) assistiu a uma revolução invertida que não era retórica, daí a relevância do La Moneda em chamas. Nas palavras do Ministro da 
Defesa, Patrício Carvajal, foi necessário e conveniente bombardear La Moneda: “foi um golpe tão forte, tão fulminante, tão dramático, que convenceu o resto do povo, que podia fazer alguma coisa, que isto iria ser muito sério" (apud AGGIO, 2002, p. 31). Avanzar sin transar - a utopia que alimentou uma esquerda que acreditava ser possível desapropriar riquezas e estatizá-las para fundar e promover uma economia socialista, mais distributiva e igualitária - não podia se concretizar nem como devir, posto que à retórica transformadora e provocativa da UP respondeu-se com um golpe militar que, em nenhum instante, tergiversou sobre a sua ação. $O$ regime militar chileno não pretendia "salvar a sociedade do marxismo e entregá-la às elites civis" (como parecia ser a promessa brasileira), seu desejo era de eternidade e a ele se associou a onipotência ávida por transformar a nação e os homens que nela viviam. Provas desse desejo se encontram, sem muito titubear: a concentração dos presos políticos na Ilha de Dawson (com o objetivo de que esses "esquecessem o que eram antes"), a tortura publicizada", as reformas de 1977, a Constituição de 1980, o Plebiscito de 1988, a senatoria vitalícia, dentre outras.

Seguindo o raciocínio até agora defendido, para os chilenos, a reelaboração do trauma se encontra em curso, mas não é factível. Não podem incorporar a festa e seu futuro lhes foi roubado. Falta-lhes um Octávio Paz para esmiuçar a profundidade da mudança: hoje, não podem mais nem adotar a face da Unidade Popular e nem a do regime militar; são "pachucos", à outra moda. Têm de lidar com "a coisa transformada", o Chile Atual, nos dizeres de Tomás Moulian (1997, p. 382),

Este Chile provém de uma revolução capitalista que surgiu derrotando o projeto de outra, a via chilena ao socialismo. Todavia, o Atual tem conseguido sacralizar-se, tem sido consagrado como natural. Essa operação nos nega o direito ao futuro, a realizar a alusão borgiana 'agora, quero acordar do porvir'”.

Como processo em curso, resta-nos aguardar que o futuro seja restituído pela aceitação da transformação, para a qual o trauma é marca presente e coletiva.

\footnotetext{
${ }^{11}$ Não é prática usual aos regimes a publicização da tortura; o regime militar chileno assim o fez porque esse dispositivo funcionou para a sociedade chilena como ensinamento e disciplinarização. Se a ação do terror foi privada no momento de sua validação, não deixou de ser pública e ostensiva como marco do poder. Por isso, a corporação militar "queria ocultar os executores, mas desejava tornar públicos seus atos. Preferia não sair nos jornais, mas aspirava a que seus prodígios de onipotência se transmitissem em viva voz e aumentassem seu prestígio. Queria que o medo se espalhasse." (MOULIAN, 1997, p. 189)
}

\section{GANPHLAC}

Revista Eletrônica da ANPHLAC, ISSN 1679-1061, No. 17, p. 59-86, jul./dez. 2014. http://revista.anphlac.org.br/ 
Ainda examinando a permanência do trauma na América Latina contemporânea, a segunda narrativa da qual nos ocuparemos advém do campo literário. As relações entre sonho e realidade ou tradição e utopia reaparecem em Gabriel García Márquez, o escritor colombiano que ganhou o Prêmio Nobel de Literatura em 1982. Para esse autor, os cronistas das Índias, que tratavam de construir as narrativas sobre a América a serem digeridas na Europa, foram os primeiros a legar um material precioso para os romances contemporâneos. Considerado fundador do realismo mágico, Gabriel García Márquez sugere que, para além da intimidade entre a literatura latino-americana e a história, as narrativas literárias deságuam no desafio de tornar a experiência americana crível. Diante do olhar do outro e do desejo de se enquadrar na expectativa desse outro, a América não precisou pedir muito à imaginação, uma vez que a sua realidade parecia etérea, pronta para a intervenção utópica. Quase ao final de seu discurso na Academia Sueca de Letras, o colombiano anota: "a violência e a dor desmedidas da nossa história são o resultado de injustiças seculares e amarguras sem conta, não uma confabulação urdida a três mil léguas de nossa casa. Diante da opressão, do saque e do abandono, a nossa resposta é a vida” (GARCÍA MÁRQUEZ, 2011, p. 11). Mais uma vez, o trauma (e a utopia que lhe acompanha) é reatualizado.

Por fim, apenas para contribuir com as reflexões apresentadas, retornemos ao Brasil, essa outra América, com a intenção de que a comparação nos permita enxergar melhor a cultura política que fundamenta, ao mesmo tempo, a diversidade e a singularidade hispano-americana. Nossa relação com a colonização portuguesa é distinta, assim como também é distinta a nossa relação com o Império. A política que urdiu e ordenou nossa passagem à condição de país independente nos fez independentes pelas mãos de um príncipe português. Desconhecemos, nesse sentido, o trauma como elemento fundador da nação - ao menos, no que se relaciona à forma pela qual se divulgará a ideia de nação. Ao fazer história, ao constituir uma narrativa sobre si, a nação positivará a ação ibérica. Talvez isso explique o nosso desapego aos heróis, que, por formação e por sorte nossa, não precisam ser convocados a resolver os dilemas cotidianos. Nosso trauma, distinto dos países da América Hispânica, incide sobre a escravidão. Aos poucos, nos acercamos dele e, como se trata de trauma, não deixamos de criticar a democratização social, acusada de ser demasiadamente rápida. Não seria diferente, afinal essa democratização coloca como responsabilidade coletiva o

\section{GANPHLAC}

Revista Eletrônica da ANPHLAC, ISSN 1679-1061, Nº. 17, p. 59-86, jul./dez. 2014. http://revista.anphlac.org.br/ 
enfrentamento cotidiano de nossa formação histórica. Sem dúvida, assim como admitimos a pluralidade da América Hispânica, é fundamental esclarecer que o trauma em relação à escravidão nos parece o mais proeminente; no entanto, não é, de modo algum, único. Essa diferença (e a semelhança, demarcada pela sujeição à colonização) reforça nossa resistência a integrar a América Latina e torna ainda mais válida a leitura que nós, brasileiros, fazemos da América. Por fim, a escrita ensaística, a literatura e a historiografia, dentre outras manifestações da experiência, presentificam o trauma como elemento intrínseco à cultura hispano-americana. Colocar em diálogo essas narrativas permite conhecer melhor as temporalidades americanas e a gestão da memória nessa região - é essa gestão que mantém viva a utopia.

\section{Referências documentais e bibliográficas}

ACHUGAR, Hugo. Planetas sem boca - Escritos efêmeros sobre arte, cultura e literatura. Belo Horizonte: Editora UFMG, 2006.

AGGIO, Alberto. Democracia e socialismo: a experiência chilena. São Paulo: Anablume, 2002.

AGGIO, Alberto. Uma insólita visita: Fidel Castro no Chile de Allende. História. Revista da Universidade Estadual Paulista, ISSN 1980-4369, vol. 22, n. 02, 2003. Disponível em: <http://www.scielo.br/scielo.php?pid=S010190742003000200009\&script=sci_arttext $>$. Acesso em: 30 nov.2014.

ALLENDE, Salvador. Programa básico de governo da Unidade Popular. In: CARLOS, Newton; FREITAS, Galeno de; VETTORI, Márcia. Chile com Allende para onde vai? Rio de Janeiro: Editora Grenasa, 1970. p. 89-119.

BILBAO, Francisco. El evangelio americano. Buenos Aires: Imp. de la Soc. Tip. Bonaerense, 1864.

BORGES, Jorge Luis. O Martin Fierro. Traduzido por Carmem Vera Cirne Lima. Porto Alegre: LP\&M, 2013.

CÁCERES, Gonzalo Quiero; ALCÀZAR I GARRIDO, Joan Del. Allende y la Unidad Popular: hacia uma desconstrucción de lós mitos políticos chilenos. In: CEME/Archivo del Chile, 2005. Disponível em: http://www.archivochile.com/S_Allende_UP/doc_sobre_gob_UP/SAgobsobre0015.pdf. Acesso em: 17.06.2014.

\section{GANPHLAC}

Revista Eletrônica da ANPHLAC, ISSN 1679-1061, No. 17, p. 59-86, jul./dez. 2014. http://revista.anphlac.org.br/ 
CASTAÑEDA, Jorge G. O crisol cubano. In: Utopia desarmada: intrigas, dilemas e promessas da esquerda latino-americana. São Paulo: Companhia das Letras, 1994, p. $55-83$.

CORTEZ, Irlemar Chiampi. O discurso americanista dos anos 20. In: Discurso 9, São Paulo: Livraria Editora Ciências Humanas, 1979.

DORFMAN, Ariel. O longo adeus a Pinochet. São Paulo: Companhia das Letras, 2003.

FREDRIGO, Fabiana de Souza. Guerras e escritas: a correspondência de Simón Bolívar (1783-1830). São Paulo: Editora UNESP, 2010.

FUENTES, Carlos. O espelho enterrado: reflexões sobre a Espanha e o Novo Mundo. Rio de Janeiro: Rocco, 2001.

GARCÍA MÁRQUEZ, Gabriel. A solidão da América Latina. In: Cem anos de solidão. Rio de Janeiro: Editora Record, 2011, p. 7-13.

GOYENECHE, José Alberto Bravo de (Editor). Bilbao: el autor y la obra (Obras Completas). Santiago: Editorial Cuarto Propio, 2007.

GUERRA, François-Xavier. La ruptura originaria: mutaciones, debates y mitos de la independência. In: DAMAS, Germán Carrera et al. Mitos políticos en las sociedades andinas - origenes, invenciones y ficciones. Caracas: Equinoccio Editorial, 2006.

GUERRA, François-Xavier. Memórias em transformação. [Tradução e adaptação de Jaime de Almeida da introdução de GUERRA, François-Xavier (Org.). Memóires en Devenir. Amérique Latine XVI-XXe. siècle. Bordeaux, Maison dês Pays Ibériques, 1994, p. 9-27].

HARTOG, François: Regime de Historicidade - Time, History and the Writing of History: the order of time. KVHAA Konferenser 37: 95-113, Stockholm, 1996.

HERNANDÉZ, José. Martín Fierro. Tradução João Otávio Nogueira Leiria. Porto Alegre: Editora Martins, 1987.

KOSELLECK, Reinhart. Futuro passado: contribuição à semântica dos tempos históricos. Rio de Janeiro: Contraponto/Editora da PUC-Rio, 2006.

LACAPRA, Dominick. Repensar la historia intelectual y leer textos. In: PALTI, Elías José (Org): "Giro lingüístico" e historia intelectual. Buenos Aires: Universidad Nacional de Quilmes, 1998.

LECUNA, V. (Org.). Cartas del Libertador (1821-1823). 2. ed. Caracas: Fundación Vicente Lecuna; Banco de Venezuela, 1965. Tomo III. 559 p.

\section{CANPHLAC}

Revista Eletrônica da ANPHLAC, ISSN 1679-1061, Nº. 17, p. 59-86, jul./dez. 2014. http://revista.anphlac.org.br/ 
LIRA, Andrés. Justo Sierra: la historia como entendimiento responsable. In. FLORESCANO, Enrique, PÉREZ, Ricardo (Compiladores). Historiadores de México en el siglo XX. México: Fondo de Cultura Econômica, 1996.

MARTINS, E. C. R. Consciência histórica, práxis cultural e identidade nacional. In: SERPA, Elio Cantalício et al. Escritas da história: intelectuais e poder. Goiânia: Editora da Universidade Católica, 2004, p. 11-34.

MOULIAN, Tomás. Chile actual - anatomía de um mito. Santiago do Chile: Arcis Universidad: Lom Ediciones, 1998.

ORTEGA y GASSET, José. España invertebrada. Madrid; Revista de Occidente: Alianza Editorial, 1993.

PAZ, Octavio. Entrevista com Rita Guibert. In: Huellas del peregrino: vistas del México Independiente y revolucionário. México: FCE, 2010, p. 251-307.

PINTO VALEJOS, Julio. Os fantasmas da Unidade Popular: um vazio inquietante na historiografia chilena. Revista Eletrônica da ANPHLAC, n. 14, p. 31-42, jan./jun. 2013. Disponível em: http://revista.anphlac.org.br/index.php/revista. Acesso em: 22 fev. 2015.

PRADO, Maria Lígia Coelho. América Latina: tradição e crítica. Revista Brasileira de História, São Paulo, n. 2, p. 167-174, set. 1981.

PRATT, Mary Louise. Os olhos do império - relatos de viagem e transculturação. Bauru: São Paulo: EDUSC, 1999.

ROUQUIÉ, Alain. O extremo Ocidente: introdução à América Latina. São Paulo: EDUSP, 1987.

RÜSEN, Jörn. Razão histórica - Teoria da história: os fundamentos da ciência histórica. Brasília: Editora da Universidade de Brasília, 2001.

SÁBATO, Hilda. Horizontes republicanos en Iberoamérica. Una perspectiva de largo plazo. In: BRAGONI, Beatriz; MATA Sara E. Entre la colônia y la República Insurgencias, rebeliones y cultura política en América del Sur. Buenos Aires. Prometeo Libros, 2008.

SIERRA, Justo. Evolución política del pueblo mexicano. México: Editorial Porrua, 1986.

THEODORO, Janice. América barroca: temas e variações. São Paulo: Editora da Universidade de São Paulo/Editora Nova Fronteira, 1992.

TODOROV, T. A conquista da América: a questão do outro. São Paulo: Martins Fontes, 1993.

\section{GANPHLAC}

Revista Eletrônica da ANPHLAC, ISSN 1679-1061, Nº. 17, p. 59-86, jul./dez. 2014. http://revista.anphlac.org.br/ 
VEYNE, Paul. Tudo é singular na história universal: o "discurso". In: Foucault: seu pensamento, sua pessoa. Rio de Janeiro: Civilização Brasileira, 2011. p. 13-40.

\section{GANPHLAC}

Revista Eletrônica da ANPHLAC, ISSN 1679-1061, Nº 17, p. 59-86, jul./dez. 2014. http://revista.anphlac.org.br/ 